\title{
Trophic model of the outer continental shelf and upper slope demersal community of the southeastern Brazilian Bight
}

\author{
MARCELA C. NASCIMENTO ${ }^{1,2}$, GONZALO VELASCO ${ }^{3}$, THOMAS A. OKEY ${ }^{4,5}$, \\ VILLY CHRISTENSEN ${ }^{6}$ and A. CECÍLIA Z. AMARAL ${ }^{2}$ \\ ${ }^{1}$ Programa de Pós-Graduação em Ecologia, Universidade Estadual de Campinas (UNICAMP), CP 6109, 13083-970, \\ Campinas, São Paulo, Brazil. E-mail: Nascimento_mc@yahoo.com.br \\ ${ }_{2}^{2}$ Departamento de Biologia Animal, Instituto de Biologia, Universidade Estadual de Campinas (UNICAMP), CP 6109, \\ 13083-970, Campinas, São Paulo, Brazil. \\ ${ }^{3}$ Programa de Pós-Graduação em Oceanografia Biológica, Universidade Federal do Rio Grande, Rio Grande, PO Box 474, \\ CEP 90201-900, RS, Brazil. \\ ${ }^{4}$ School of Environmental Studies, University of Victoria, PO Box 3060 STN CSC BC, Victoria, BC V8W 3R4, Canada. \\ ${ }^{5}$ School of Earth and Ocean Sciences, PO Box 3065 STN CSC, University of Victoria, Victoria, BC V8W 3V6, Canada. \\ ${ }^{6}$ Fisheries Centre, University of British Columbia, 2202 Main Mall, Vancouver, BC V6T 2K9, Canada.
}

SUMMARY: It is increasingly recognized that demersal communities are important for the functioning of continental shelf and slope ecosystems around the world, including tropical regions. Demersal communities are most prominent in areas of high detritus production and transport, and they link benthic and pelagic biological communities. To understand the structure and role of the demersal community on the southeastern Brazilian Bight, we constructed a trophodynamic model with 37 functional groups to represent the demersal community of the outer continental shelf and upper slope of this area, using the Ecopath with Ecosim 6 (EwE) approach and software. The model indicates high production and biomass of detritus and benthic invertebrates, and strong linkages of these components to demersal and pelagic sub-webs. The level of omnivory indexes in this ecosystem was high, forming a highly connected trophic web reminiscent of tropical land areas. Although high levels of ascendency may indicate resistance and resilience to disturbance, recent and present fisheries trends are probably degrading the biological community and related ecosystem services.

Keywords: modelling, demersal community, Brazil, Brazilian Exclusive Economic Zone, deep sea, ecosystem, southeastern Brazil.

RESUMEN: MODELO TRÓFICO DE LA COMUNIDAD DEMERSAL DE LA PLATAFORMA CONTINENTAL EXTERIOR Y TALUD SUPERIOR DE LA CUENCA DEL Sudeste DE BRASIL. - La importancia de las comunidades demersales para el funcionamiento de los ecosistemas de plataforma continental y talud son reconocidos alrededor del mundo, incluyendo las regiones tropicales. Esas comunidades son más prominentes en áreas con gran producción y transporte de detrito. Para entender la estructura y funcionamiento de la comunidad demersal en la Ensenada Sureste Brasileña, construimos un modelo trofodinámico con 37 grupos funcionales para representar la comunidad demersal de la plataforma continental externa y el talud superior de esa región, utilizando el paquete Ecopath con Ecosim 6 (EwE). El modelo indica que el detrito y los invertebrados son muy abundantes e importantes en la estructura de este ecosistema. El nivel de omnivoría encontrado en este ecosistema fue alto, conformando una red trófica altamente conectada, a semejanza del de las áreas tropicales terrestres.

Palabras clave: modelización, comunidad demersal, Brasil, ZEE de Brasil, aguas profundas, ecosistema, Sudeste de Brasil.

\section{INTRODUCTION}

Demersal communities are often very developed on continental shelves and slopes, especially in temper- ate zones. This occurs because of the abundance of detritus-based food resources from water-column and nearshore production cycles and coastal watersheds, and the consumption of this detritus by bacteria, inver- 
tebrates and vertebrates. Many of the dominant fishes inhabiting such areas are demersal, feeding largely on benthic invertebrates (e.g. Morato et al. 1999, Martins et al. 2005, Muto 2005, Velasco and Castello 2005, Carvalho and Soares 2006, Bautista-Vega et al. 2008). The abundance of these fish communities is reflected in their catches. In Brazil, demersal species (including fishes and invertebrates) represent about $35 \%$ of the total fishery landings (IBAMA 2008). Because of the intense exploitation of these resources, many species are overexploited or at risk of collapse (Rossi-Wongtschowski et al. 2006, Valentini and Pezzuto 2006, Velasco et al. 2007). In Brazil this situation is worsened by the lack of knowledge about these biological communities, particularly in deep sea areas, owing to only minimal investment in research and the lack of specific fisheries statistics.

Aiming to improve information about marine life in Brazil, in 1995 the project "Avaliação do potencial sustentável de recursos vivos na Zona Econômica Exclusiva do Brasil" (Assessment of the sustainable potential of living resources in the Brazilian Exclusive Economic Zone - REVIZEE) began to rectify the situation by making an inventory of the living resources along the Brazilian Exclusive Economic Zone (EEZ). This information can be used to estimate the biological composition and diversity of the various marine habitats in this area and, for instance, to estimate the abundance and biomass of various species in each habitat and understand their interdependence and vulnerabilities. This research foundation led to additional studies of diet composition, growth, population biology and ecosystem ecology (e.g. Muto et al. 2005, Nascimento 2006, Gasalla et al. 2007, Vaz-dos-Santos and RossiWongtschowski 2007, Eleuterio 2008). In the present study, information from these previous studies was used to construct a trophodynamic model of the Brazilian Bight's outer slope and upper continental shelf to refine our understanding of the system as a whole.

The Brazilian EEZ extends beyond the continental slope along most of its length, and the slope fishery is very recent, having begun during the late 1990s (Perez et al. 2001, 2002, 2002b). This fishery was highly encouraged by the government, leading to an unregulated fishery. The REVIZEE-Score Sul project consequently detected overexploitation of many species in its 20002004 analysis (Valentini and Pezzuto 2006).

The present study is focused on the REVIZEE-Score Sul observations from the southeastern Brazilian Bight area, between Cabo Frio at $22^{\circ} \mathrm{S}$ and Cabo de Santa Marta Grande at $27^{\circ} \mathrm{S}$. This is one of the most productive areas of the Brazilian sea, responsible for approximately $40 \%$ of Brazilian fish catches (IBAMA 2008). This area is also a large embayment, and populations restricted to this area in Brazilian waters include the Argentine hake (Merluccius hubbsi) stock (Vaz-dos-Santos 2006, Vazdos-Santos and Rossi-Wongtschowski 2007) and the Brazilian-sardine (Sardinella brasiliensis) stock (Saccardo 1983). This area is naturally-defined by its geogra- phy, oceanography and biology, and is thus suitable for modelling as a whole.

The main fishery resources in this area are demersal and benthic organisms such as fishes (teleosts and chondrichthyans) and invertebrates (molluscs and crustaceans). Some of the fish species such as Argentine hake (Merluccius hubbsi), Brazilian cod (Urophycis mystacea) and blackfin goosefish (Lophius gastrophysus) were previously discarded or used as bait, but now feature in the landings. Most of these species are now fully exploited or overexploited (Valentin and Pezzuto 2006). Also, the REVIZEE-Score Sul studies showed some abundant species that were not exploited but were important in the diet composition of targeted species. The stomach contents of some of these species (Antigonia capros, a bentho-pelagic invertebrate feeder; Ariomma bondi and Ventrifossa macropogon, benthic invertebrates feeders; Synagrops spinosus and Synagrops bellus, benthic fish and crustacean feeders; and the commercial fishes Urophycis mystacea and Genypterus brasiliensis, which live and feed near the bottom) were sampled by MCN, GV, and ACZA (unpublished data) and by Nascimento (2006). These diet studies indicate the importance of these species in linking the benthos with upper trophic levels, as many feed on benthos directly and are in some cases prey for top predators.

Although some trophic studies have been performed in this area, we felt that they had underemphasized the benthic community, which has a high biomass and may provide important ecological services. We therefore set out to investigate the ecological importance of the benthic community in this setting by articulating it in the model so that associated flows and dynamics could emerge from the present summaries and later dynamic analyses.

As mentioned above, exploitation of the demersal community of the outer continental shelf and upper slope of the southeastern Brazilian Bight began a decade ago, and it has reached high exploitation levels and is largely unrestricted. A main objective of this research is to understand how fisheries might affect this community, how global scale environmental change (i.e. climate change) may affect it, and how these effects may be combined. The present study is the first step in this research to construct a trophodynamic characterization of this highly developed demersal and bentho-pelagic community.

\section{MATERIAL AND METHODS}

\section{Study area}

The study area was the outer continental shelf and upper slope of the southeastern Brazilian Bight, located between Cabo Frio $\left(22^{\circ} \mathrm{S}\right)$ and Cabo de Santa Marta Grande $\left(27^{\circ} \mathrm{S}\right)$. A large-scale boundary current, the Brazil Current, flows poleward along and beyond the continental shelf break of the Brazilian Bight. This cur- 


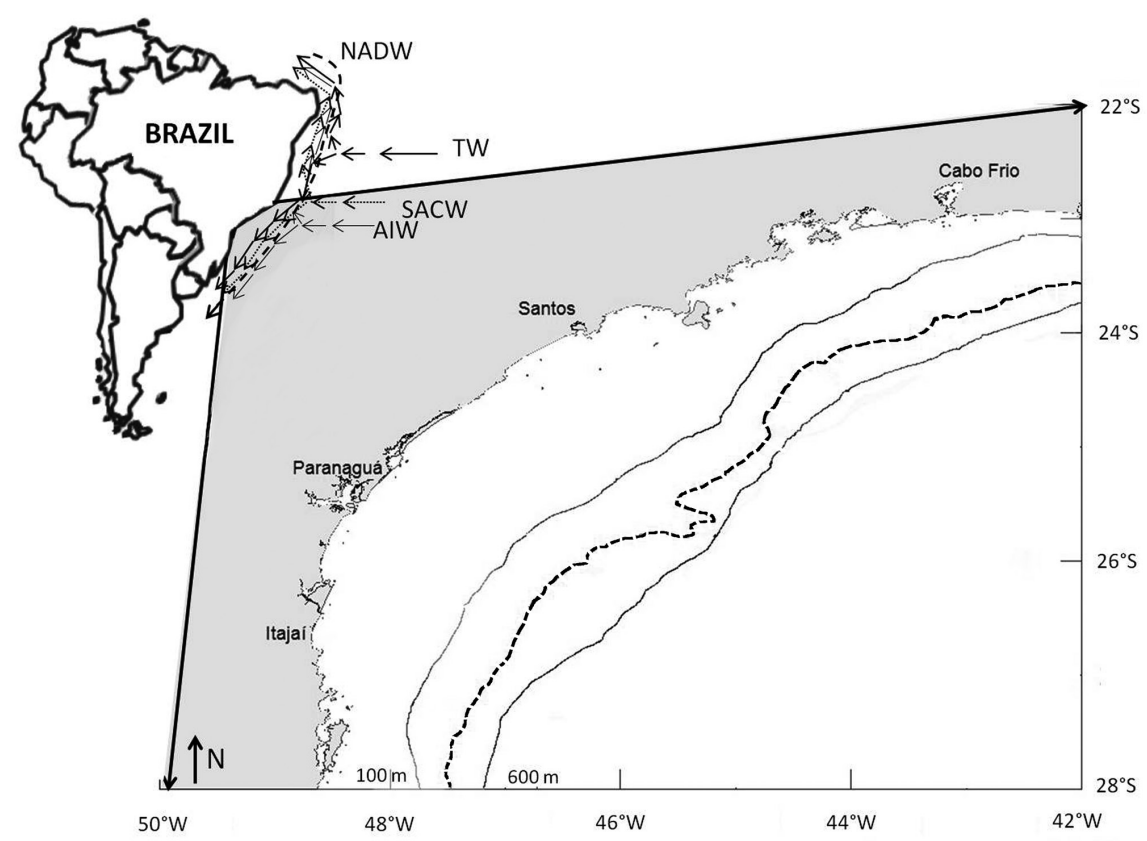

Fig. 1. - Map of the modelled area (between 100 and $600 \mathrm{~m}$ ). This drawing is based on REVIZEE (MMA 2006). The dashed line represents the continental shelf break $(200 \mathrm{~m})$. Arrows represents the main currents: South Atlantic Central Water (SACW); Antarctic Intermediate Water (AIW); Tropical Water (TW); North Atlantic Deep Water (NADW).

rent, along with the alongshore and cyclonic curl of the wind stress over the Bight, forms a doming of the density structure and this all drives closed gyral circulation cells within the Bight. In addition, there is an intense coastward penetration of cool South Atlantic Central Water (SACW) over the continental shelf floor during the summer season. The SACW contrasts with the overlying warm, tropical surface water, resulting in a strong two-layer vertical stratification, a strong thermocline at depths of 10 to $15 \mathrm{~m}$, and corresponding stability of the water column (Bakun 1996, MMA 2006, Rossi-Wongtschowski and Madureira 2006; Fig. 1).

This site was extensively sampled during the REVIZEE-Score Sul project. The fish community was sampled by bottom trawl surveys in the isobaths 100 , 150, 200, 300, 400, 500 and $600 \mathrm{~m}$ between the winter of 2001 and the autumn of 2002 (Haimovici et al. 2008). The invertebrate community was collected by conical traps (for crabs) between autumn 1996 and spring 1998 and by van Veen benthic samplers, box-corers and rectangular dredges between summer 1997 and autumn 1998 (Amaral and Rossi-Wongtschowski 2004).

The modelling area of $81658 \mathrm{~km}^{2}$, based on Haimovici et al. 2008, includes the outer continental shelf and upper slope between 100 and $600 \mathrm{~m}$. The model represents the year 2001 when most fish samples were collected, although a large part of the invertebrate data were collected in the 1990s. The main fish species of this system were defined by Haimovici et al. 2008, comprising about $80 \%$ of the total fish biomass of this system in 2001, and these made up the fish functional groups in the model. A number of fish species were therefore not included in this iteration of the model because of practical limitations of data and analytical time, but these can be included in future model iterations with additional efforts.

To build the trophic model we used Ecopath with Ecosim version 6, a modelling tool initially developed by Polovina (1984) and further developed since then (Christensen and Pauly 1992, Walters et al. 1997, Christensen and Walters 2004, Christensen et al. 2008). This program can be used to build a mass balanced model that provides a quantitative representation of the ecosystem in terms of trophic flows and biomasses for a defined time period (Velasco and Castello 2005, Coll et al. 2007, Christensen et al. 2008). The ecosystem is represented by functional groups, which can be single species, groups of ecologically related species, or ontogenetic stages of a species. The key principle of Ecopath is mass balance i.e. the energy of one group is used by another or is recycled via detritus, a portion of which re-enters the system through detritivores and as nutrient that is consumed by primary producers (Christensen et al. 2008). Two linear equations represent the energy balance within a group and the energy balance among groups.

$$
P_{i}=Y_{i}+B_{i} \times M 2_{i}+E_{i}+B A_{i}+P_{i}\left(1-E E_{i}\right)
$$

where $P_{i}$ is the total production rate of $i ; Y_{i}$ is the total fishery catch rate of $i ; B_{i}$ is the biomass of the group; $M 2_{i}$ is the total predation rate for group $i ; E_{i}$ is the net migration rate (emigration - immigration); $B A_{i}$ is the biomass accumulation rate for $i$; while $M 0_{i}=P_{i} \times(1-E E)$ is the "other mortality" rate for $i . E E_{i}$ is the ecotrophic efficiency of $i$ and is the proportion of production used 
in the system, e.g. by predators, in biomass accumulation, in migration or in export.

Equation 1 can be re-expressed as:

$$
\begin{gathered}
B_{i} \times(P / B)_{i}-\sum_{j-1}^{n} B_{j} \times(Q / B)_{j} \times D C_{j i}-(P / B)_{i} \times B_{i} \times\left(1-E E_{i}\right)- \\
-Y_{i}-E_{i}-B A_{i}=0
\end{gathered}
$$

where $(P / B)_{i}$ indicates the production of $i$ per unit of biomass and is equivalent to total mortality, or $\mathrm{Z}$, under static conditions (Allen 1971); $(Q / B)_{i}$ is the consumption of $i$ per unit of biomass; $D C_{i j}$ indicates the proportion of prey $i$ that is in the diet of predator $j$ in terms of volume or weight units. Ecopath parameterizes the model by describing a system of linear equations for all the functional groups in the model (Christensen and Walters 2004, Christensen et al. 2008).

The second Ecopath equation is:

$$
Q_{i}=P_{i}+X_{i}+R_{i}
$$

where $Q_{i}$ is the consumption rate of prey $i$ per unit of biomass, $P_{i}$ is the production of prey $i$ per unit of biomass, $X_{i}$ is the combined excretion and egestion rate of prey $i$, and $R_{i}$ is the respiration rate. To parameterize the model, three out of four basic parameters must be provided: biomass $(B)$, production/biomass $(P / B)$, consumption/biomass $(Q / B)$, and ecotrophic efficiency $(E E)$; the algorithm then estimates the fourth parameter so as to ensure mass balance. Diet composition, catch data, food assimilation, migration and biomass accumulation are also required inputs.

Some of the necessary input parameters were calculated from our own field data (from REVIZEEScore Sul), based on the mean temperature of water at the most frequent depth where each species occur (annual mean temperature of each depth is based on CTD data from trawl surveys). The estimation of $Q / B$ was based on Palomares and Pauly (1998) and $P / B$ was based on Jorgensen (1979); in cases of unexploited populations we used Pauly's (1980) natural mortality equation to obtain the $P / B$ value. Others were obtained from the literature. This information is summarized in Appendix 1.

The biological community of the outer continental shelf and upper slope of the southeastern Brazilian Bight was divided into 37 functional groups to build the model. Of these groups 12 were invertebrates, 21 were fishes, 2 were detritus (detritus and marine snow) and 1 was phytoplankton; this last group was included as an input for marine snow and in this case all excess production of phytoplankton was converted to marine snow. This effectively means that marine snow is made up of detritus in the system, so the phytoplankton source is used as a proxy for the more diverse sources and feedbacks of marine snow, including microbial loop dynamics. These groups were defined on the basis of habitat, body size, type of food, biology, ecology and physiology of the most abundant and economically important species. The main references for building these groups are Haimovici et al. (2008), and Amaral and Rossi-Wongtschowski (2004), who describe the fish demersal and benthos community respectively. The other references used are listed in Appendix 1. Gasalla et al. (2007) built a model of the area from Cabo Frio (RJ) to southern Brazil (Chuí - RS) between 100 and $1000 \mathrm{~m}$ depth. This initial trophodynamic modelling work in this region synthesized a large amount of knowledge about this system, particularly regarding demersal and pelagic species, which were the focus of that model. Although the model described in the present paper includes part of the area modelled by Gasalla et al. (2007), we focused more on the demersal and benthic community, providing more detail about this community, recognizing the importance of benthic and demersal invertebrates for the structure, functions and flows of the broader biological community. The functional groups of the present southeastern Brazilian Bight model and the main species comprising them are listed in Table 1.

The main commercial species are Lophius gastrophysus (blackfin goosefish); Urophicis mystacea (Brazilian cod); Trichiurus lepturus (cutlassfish); Helicolenus lahillei (blackbelly rosefish); Lopholatilus villarii (tile fish); Merluccius hubbsi (Argentine hake); Prionotus punctatus (searobin) and Pagrus pagrus (red porgy), here represented as a single-species functional group; and Paralichthys sp. (flounders) and Illex argentinus (squid), here represented as a multispecific functional group. The majority of catches were based on trawls and longline fisheries (Valentini and Pezzuto 2006). Many of these species used to be discarded by the fleets fishing for shrimp, flounder and pelagic species, but in the last 20 years they have become commercial species. Currently, some of these species are overexploited (Rossi-Wongtschowski et al. 2006, Valentini and Pezzuto 2006). Also crabs, shrimps, and squids support important fisheries in the area, being among the most important resources, and some species of shrimps and crabs are also at risk of overexploitation (Valentini and Pezzuto 2006, IBAMA 2008).

Argentine hake is an important resource in terms of biomass and catch in the area. It is known that the diet of this species differs considerably between life stages, and it exhibits a high level of cannibalism (Angelescu and Prenski 1987, Bezzi et al. 1994, Brown et al. 2004). Therefore, to ensure consistency between ontogenetic groups (juveniles and adults), a multi-stanza representation (Christensen and Walters 2004) was used for modelling this group. Two groups were defined considering the diet composition and behaviour: Juveniles with lengths of less than $28 \mathrm{~cm}$, and adults with lengths of more than $28 \mathrm{~cm}$ (Vaz-dos-Santos et al. 2009). (P/B) and diet composition were provided for both groups from Bezzi et al. (1994), Brown et al. (2004) and Sánches (2009).

The fishing statistics we used for the model were based on the official statistic of the Ministry of the Environment (MMA). We specified a rate of fishery 
TABLE 1. - Name and main components of each functional group.

\begin{tabular}{|c|c|c|}
\hline $\begin{array}{l}\text { Blackfin goosefish } \\
\text { Lophius gastrophysus }\end{array}$ & $\begin{array}{l}\text { Demersal fishes } \\
\text { Mullus argentinae }\end{array}$ & Munida spp. \\
\hline $\begin{array}{l}\text { Lopnius gastropnysus } \\
\text { Cutlassfish }\end{array}$ & $\begin{array}{l}\text { Mullus argentinae } \\
\text { Polvmixia lowei }\end{array}$ & $\begin{array}{l}\text { Scyllarides deceptor } \\
\text { Shrimns }\end{array}$ \\
\hline Trichiurus lepturus & $\begin{array}{l}\text { Polymixia lowei } \\
\text { Chilomycterus spinosus }\end{array}$ & Shrimps \\
\hline Rosefish & & Alpheus spp. \\
\hline Helicolenus lahillei & $\begin{array}{l}\text { Dactylopterus volitans } \\
\text { Bellator brachychir }\end{array}$ & Heterocarpus spp. \\
\hline Tile fish & Saurida sp. & Acanthephyra spp. \\
\hline Lopholatilus villarii & Benthic fishes & Oplophorus sp. \\
\hline Argentine hake & Paralichthys isosceles & Bivalves \\
\hline Merluccius hubbsi & Paralichthys patagonicus & Corbula spp. \\
\hline Searobin & Paralichthys triocellatus & Limopsis janeiroensis \\
\hline Prionotus punctatus & Bembrops heterurus & Polychaetes \\
\hline Red porgy & Raneya brasiliensis & Exogone (Exogone) sp. \\
\hline Pagrus pagrus & Skates & Nereis spp. \\
\hline Demersal sharks & Atlantoraja cyclophora & Diopatra spp. \\
\hline Mustellus sp. & Atlantoraja platana & Kinbergonuphis spp. \\
\hline Squalus sp. & Predator crustaceans & Moоreопирhis spp. \\
\hline Carcharhinus sp. & Hemisquilla brasiliensis & Nothria spp. \\
\hline Heptranchias perlo & Squilla sp. & Eunicidae \\
\hline Argentine croaker & Predator molluscs & Pseudovermilia occidentalis \\
\hline Umbrina canosai & Conus villepinii & Sphaerosyllis (Prosphaerosyllis) sp. \\
\hline Bentho-pelagic fishes & Chicoreus sp. & Spiophanes berkeleyorum \\
\hline Caelorinchus marinii & Polinices lacteus & Spiophanes spp. \\
\hline Xenolepidichthys dalgleishi & Nassarius sp. & Micronereides capensis \\
\hline Sphoeroides pachygaster & Bursa ranelloides tenuisculpta & Pseudovermilia sp. \\
\hline Beryx splendens & Conus mazei & Ampharetidae \\
\hline Large bentho-pelagic fishes & Calliostoma sp. & Other detritivore invertebrates \\
\hline Lepidopus altfrons & Nanomelon viperinus & Pyura sp. \\
\hline Malacocephalus occidentalis & Symplectoscyphus sp. & Ophiura ljungmani \\
\hline Thyrsitops lepidopoidees & Scaeurgus unicirrhus & Ophiura sp. \\
\hline Zenopsis conchifera & Vosseledone charrua & Ophiomisidium pulchellum \\
\hline Deepbody boarfish & Eudendrium sp. & Ophiothrix rathbuni \\
\hline Antigonia capros & Acryptolaria sp. & Amphiura complanata \\
\hline Silver-rag driftfish & Ancilla sp. & Raspailia spp. \\
\hline Ariomma bondi & Nanomelon sp. & Cupuladria sp. \\
\hline Pink cusk-eel & Eledone massyae & Discoporella umbellata \\
\hline Genypterus brasiliensis & Octopus vulgaris & Bouchardia rosea \\
\hline Synagrops sp. & Other predator invertebrates & Democrinus sp. \\
\hline Synagrops bellus & Nausithoe sp. & Infauna \\
\hline Synagrops spinosus & Atorella sp. & Nematoda \\
\hline Brazilian cod & Ctenodiscus sp. & Nephasoma sp. \\
\hline Urophycis mystacea & Astropecten $\mathrm{sp}$. & Aspidosiphon mexicanus \\
\hline Longbeard grenadier & Allostichaster hartii & Aspidosiphon laevis \\
\hline Ventrifossa macropogon & Omnivore invertebrates & Echiura \\
\hline Squid & Acanthochitona sp. & Priapulida \\
\hline Illex argentinus & Echinocyamus grandiporus & Hemichordata \\
\hline Loligo plei & Stylocidaris lineata & Zooplankton \\
\hline Loligo sanpaulensis & Isopoda & Zooplankton \\
\hline Large demersal fishes & Amphipoda & Marine snow \\
\hline Nemadactylus bergi & Chaetognatha & Phytoplankton (not consumed by \\
\hline Epinephelus nivelatus & Crabs & the pelagic system) \\
\hline Pseudopercis numida & Chaceon spp. & Detritus \\
\hline Ariosoma opistophthalmus & Euprognatha sp. & Dead organic matter of the system \\
\hline Bassanago albescens & Stenocionops spp. & (cycled) \\
\hline Conger esculentus & Portunus spp. & \\
\hline Conger orbignianus & & \\
\hline
\end{tabular}

discards for all groups, normalized to represent $25 \%$ of the total catch, based on data from Haimovici (2007), who found a range of $24 \%$ to $53 \%$ depending on gear and species. This applied estimate was thus conservative. The input data for each functional group are shown in Table 2.

The diet matrix was based on diet composition studies. The non-fished species that represented individual functional groups, in addition to Brazilian cod and pink cusk-eel, were analysed by MCN, ACZA and GV (unpublished data). The diet information for other functional groups was based on data from the literature (Soares 1992, Tubino 1999, Muto et al. 2005, Martins et al. 2006, Rodrigues 2007). The complete reference list is in Appendix 1. The original diet matrix is shown in Table 3.

The model generated with the data was not balanced initially, 11 functional groups needed to be balanced: Argentine hake, searobin, Argentine croaker, Synagrops sp., squid, large demersal fishes, demersal fishes, benthic fishes, other predator invertebrates and omnivore invertebrates. The main problem in balancing this model was to coordinate ways to fix problems in the biomass of some groups, especially Argentine hake. This is a multistanza group that is highly fished, but only the adults are removed; the juveniles are dis- 
TABLE 2. - Input data. $\mathrm{B}_{\mathrm{i}}$, initial biomass $\left(\mathrm{t} \mathrm{km}^{-2}\right)$; EE, ecotrophic efficiency; $\mathrm{P} / \mathrm{B}$, production/biomass ratio $\left(\mathrm{yr}^{-1}\right)$; $\mathrm{Q} / \mathrm{B}$, consumption/biomass ratio $\left(\mathrm{yr}^{-1}\right)$. Landings and discards in $\mathrm{t} \mathrm{km}^{-2} \mathrm{yr}^{-1}$.

\begin{tabular}{|c|c|c|c|c|c|c|c|}
\hline & Functional groups & $\mathrm{B}_{\mathrm{i}}$ & $\mathrm{EE}$ & $\mathrm{P} / \mathrm{B}$ & $\mathrm{Q} / \mathrm{B}$ & Landings & Discards \\
\hline 1 & Blackfin goosefish & 0.115 & - & 0.3 & 2.3 & 0.0061 & 0.0003 \\
\hline 2 & Cutlassfish & 0.031 & - & 2.49 & 3.1 & 0.0011 & 0.0003 \\
\hline 3 & Rosefish & 0.016 & - & 0.07 & 4.76 & - & - \\
\hline 4 & Tile fish & 0.021 & - & 0.74 & 1.38 & 0.0006 & 0.0003 \\
\hline 5 & Argentine hake & 0.283 & - & 0.95 & 2.96 & 0.0022 & 0.0003 \\
\hline 6 & Searobin & 0.011 & - & 0.382 & 9.19 & 0.0032 & 0.0028 \\
\hline 7 & Red porgy & - & 0.95 & 0.89 & 3.4 & 0.0011 & 0.0003 \\
\hline 8 & Demersal sharks & 0.019 & - & 0.355 & 2.3215 & - & 0.0003 \\
\hline 9 & Argentine croaker & 0.075 & - & 0.6 & 4.3 & 0.0053 & 0.0003 \\
\hline 10 & Bentho-pelagic fishes & 0.085 & - & 0.404 & 4.125 & 0.000008 & - \\
\hline 11 & Large bentho-pelagic fishes & 0.472 & - & 0.3 & 3.183 & - & - \\
\hline 12 & Deepbody boarfish & 0.203 & - & 0.61 & 5.9 & - & - \\
\hline 13 & Silver-rag driftfish & 0.252 & - & 1.05 & 4.6 & - & - \\
\hline 14 & Pink cusk-eel & 0.042 & - & 0.5 & 2.8 & 0.0005 & - \\
\hline 15 & Synagrops sp. & 0.168 & - & 1.08 & 5.9 & - & - \\
\hline 16 & Brazilian cod & 0.069 & - & 0.7 & 2.5 & 0.0024 & 0.0014 \\
\hline 17 & Longbeard grenadier & 0.003 & - & 0.32 & 2.9 & - & - \\
\hline 18 & Squid & 0.256 & - & 4.6 & 36.5 & 0.0011 & - \\
\hline 19 & Large demersal fishes & 0.028 & - & 1 & 4.2 & 0.0005 & - \\
\hline 20 & Demersal fishes & 0.397 & - & 0.48 & 6.507 & 0.0008 & - \\
\hline 21 & Benthic fishes & 0.077 & - & 0.07 & 4.175 & 0.0017 & 0.007 \\
\hline 22 & Skates & 0.051 & - & 0.14 & 4.432 & 0.0019 & - \\
\hline 23 & Predator crustaceans & 0.150 & - & 4.6 & 14.45 & - & - \\
\hline 24 & Predator molluscs & 0.287 & - & 4.5 & 20 & 0.001 & - \\
\hline 25 & Other predator invertebrates & 0.899 & - & 0.5 & 20 & - & - \\
\hline 26 & Omnivore invertebrates & 0.356 & - & 5.71 & 20 & - & - \\
\hline 27 & Crabs & 1.580 & - & 3.17 & 19 & 0.0019 & - \\
\hline 28 & Shrimps & 2.673 & - & 22.01 & & 0.0107 & - \\
\hline 29 & Bivalves & 15.493 & - & 0.6 & 20.83 & 0.000003 & - \\
\hline 30 & Polychaetes & 7.709 & - & 3.5 & 20.83 & - & - \\
\hline 31 & Other detritivore invertebrates & 4.215 & - & 4.5 & 12.2 & 0.00007 & - \\
\hline 32 & Infauna & 4.215 & - & 14.6 & 40 & - & - \\
\hline 33 & Zooplankton & 3.600 & - & 104 & 248 & - & - \\
\hline 34 & Marine snow & - & - & - & - & - & - \\
\hline 35 & Detritus & - & - & - & - & - & - \\
\hline
\end{tabular}

carded, and there is also cannibalism in the population. The rest of the groups were balanced but the P/Q values very high, requiring some adjustments, mainly to the $\mathrm{P} / \mathrm{B}$ and $\mathrm{P} / \mathrm{Q}$ values.

Argentine hake, bentho-pelagic fishes, Synagrops sp. large demersal fishes, demersal fishes and benthic fishes were the most difficult groups to balance. This difficulty was probably related to the number of connections that these species have, although the majority are not fished (excluding Argentine hake and the benthic fish groups). The input data of these groups was modified with the aim of balancing the model. The modifications were based on ecological and physiological criteria. Table 4 shows the adjusted input values and several outputs and Table 5 shows the modified diet matrix.The Ecopath algorithm also calculates some key Odum's attributes used to indicate system maturity (Christensen 1995), and we present omnivory index, system omnivory index, connectance, and relative ascendency.

The omnivory index (OI) is calculated as the variance of the trophic level of a consumer's prey groups. A value of the OI close to zero means a specialized predator. A high value means that the consumer feeds on many trophic levels. The system OI is the average omnivory index of all consumers, weighted by the logarithm of the food intakes (Christensen 1995).
The connectance of the system measures the structure of the food web; it is the ratio of the number of actual links to the number of possible links. Ascendency is a measure of the average mutual information in a system, scaled by system throughput, and is derived from information theory. The relative ascendency is the system ascendency over the system capacity.

Also, Ecopath calculates a ranking of a continuum of functional group keystoneness developed by Libralato et al. (2006). Keystone species, in this case keystone functional groups, are those with high interaction strengths but low biomasses (Power et al. 1996, Okey 2004) Libralato's (2006) keystoneness index calculated by Ecopath is:

$$
\mathrm{KS}_{i}=\log \left[\varepsilon_{i}\left(1-\mathrm{p}_{i}\right)\right]
$$

where $\mathrm{KS}_{i}$ is the keystoneness index; $\varepsilon_{i}$ is the root of the sum of mixed trophic impact matrix value ${ }^{2}$ (the mixed trophic impact matrix is the positive or negative impact by one group on another); and $\mathrm{p}_{i}$ is the biomass of impacted group/total biomass (excluding detritus).

\section{RESULTS}

This food web is essentially based on detritus (Fig. 2) because it is a deep sea ecosystem, so primary pro- 


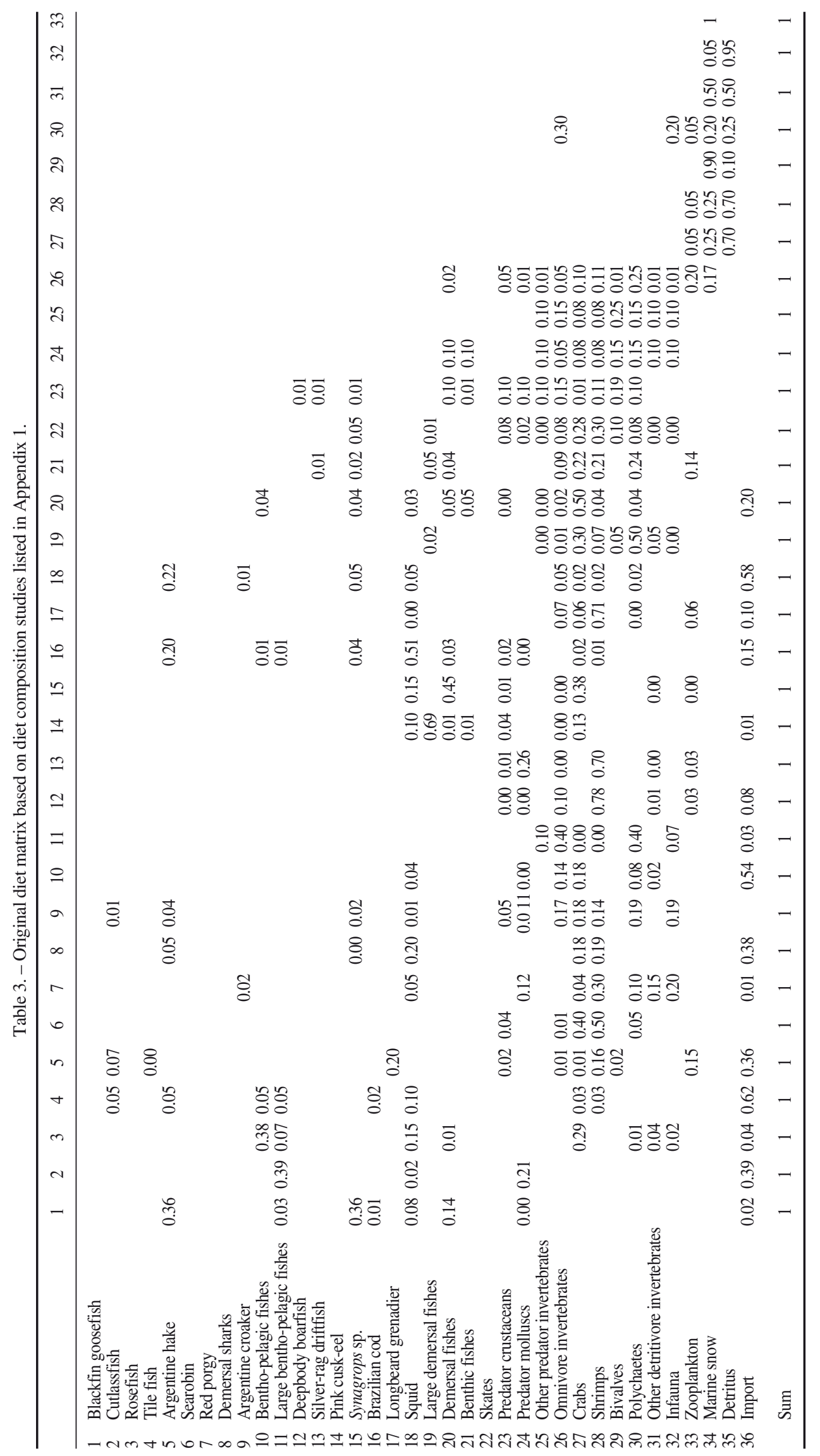


TABLE 4. - Input data modified to balance the model and the main output data. TL, Trophic level; Bf, final biomass (t km ${ }^{-2}$ ); P/B, production/ biomass ratio $\left(\mathrm{yr}^{-1}\right) ; \mathrm{Q} / \mathrm{B}$, consumption/biomass ratio $\left(\mathrm{yr}^{-1}\right)$; EE, ecotrophic efficiency; $\mathrm{P} / \mathrm{Q}$, production/consumption ratio or gross efficiency;

$\mathrm{F}$, fishing mortality $\left(\mathrm{yr}^{-1}\right)$; $\mathrm{M} 2$, predation mortality $\left(\mathrm{yr}^{-1}\right)$; Mo, other natural mortality $\left(\mathrm{yr}^{-1}\right)$; F/Z, exploitation rate; OI, omnivory index; NE, net efficiency; R/A, respiration/assimilation ratio; FD, flow to detritus ( $\left.\mathrm{t} \mathrm{km}^{-2} \mathrm{yr}^{-1}\right)$. The "input" EwE estimated parameters are in bold.

\begin{tabular}{|c|c|c|c|c|c|c|c|c|c|c|c|c|c|c|c|}
\hline & Functional groups & $\mathrm{TL}$ & $\mathrm{Bf}$ & $\mathrm{P} / \mathrm{B}$ & $\mathrm{Q} / \mathrm{B}$ & $\mathrm{EE}$ & $\mathrm{P} / \mathrm{Q}$ & $\mathrm{F}$ & M2 & M0 & $\mathrm{F} / \mathrm{Z}$ & OI & $\mathrm{NE}$ & $\mathrm{R} / \mathrm{A}$ & FD \\
\hline 1 & Blackfin goosefish & 4.708 & 0.115 & 0.4 & 2.3 & 0.572 & .174 & 0.059 & 0.170 & 0.171 & 0.149 & 0.276 & 0.217 & 0.783 & 0.072 \\
\hline 2 & Cutlassfish & 4.652 & 0.063 & 0.91 & 3.1 & 0.972 & 0.294 & 0.029 & 0.836 & 0.026 & 0.033 & 1.721 & 0.367 & 0.633 & 0.041 \\
\hline 4 & Tile fish & 4.640 & 0.021 & 0.74 & 2.5 & 0.329 & 0.296 & 0.062 & 0.182 & 0.497 & 0.083 & 2.172 & 0.370 & 0.630 & 0.021 \\
\hline 5 & Juvenile Argentine hake & 3.335 & 0.797 & 2.3 & 7.199 & 0.981 & 0.319 & 0.008 & 2.241 & 0.044 & 0.003 & 0.435 & 0.399 & 0.601 & 1.183 \\
\hline 6 & Adult Argentine hake & 4.310 & 0.360 & 0.95 & 2.7 & 0.926 & 0.352 & 0.004 & 0.876 & 0.070 & 0.004 & 1.470 & 0.440 & 0.560 & 0.220 \\
\hline 7 & Searobin & 3.161 & 0.016 & 0.38 & 2.5 & 0.527 & 0.152 & 0.197 & 0.003 & 0.180 & 0.518 & 0.135 & 0.190 & 0.810 & 0.011 \\
\hline 9 & Demersal sharks & 3.978 & 0.019 & 0.36 & 2.300 & 0.053 & 0.157 & 0.019 & 0.000 & 0.341 & 0.053 & 1.049 & 0.196 & 0.804 & 0.015 \\
\hline 10 & Argentine croaker & 3.514 & 0.090 & 0.6 & 4.3 & 0.886 & 0.140 & 0.004 & 0.528 & 0.068 & 0.007 & 0.422 & 0.174 & 0.826 & 0.083 \\
\hline 11 & Bentho-pelagic fishes & 3.640 & 0.160 & 0.73 & 4.1 & 0.719 & 0.178 & - & 0.505 & 0.205 & - & 1.102 & 0.223 & 0.777 & 0.164 \\
\hline 12 & Large bentho-pelagic fishes & 3.847 & 0.477 & 0.3 & 2 & 0.991 & 0.150 & - & 0.278 & 0.003 & - & 0.128 & 0.188 & 0.813 & 0.192 \\
\hline 13 & Deepbody boarfish & 3.159 & 0.203 & 0.61 & 5 & 0.312 & 0.122 & 0.003 & 0.158 & 0.420 & 0.005 & 0.116 & 0.153 & 0.848 & 0.289 \\
\hline 14 & Silver-rag driftfish & 3.395 & 0.252 & 1.05 & 4.6 & 0.988 & 0.228 & - & 1.037 & 0.013 & - & 0.338 & 0.285 & 0.715 & 0.235 \\
\hline 15 & Pink cusk-eel & 4.691 & 0.052 & 0.5 & 2.8 & 0.919 & 0.179 & 0.072 & 0.387 & 0.040 & 0.145 & 0.698 & 0.223 & 0.777 & 0.031 \\
\hline 16 & Synagrops sp. & 3.855 & 0.204 & 1.11 & 5.6 & 0.985 & 0.198 & - & 1.090 & 0.000 & - & 0.636 & 0.248 & 0.752 & 0.226 \\
\hline 19 & Squid & 3.967 & 0.256 & 6.7 & 36.50 & 0.981 & 0.184 & 0.003 & 6.523 & 0.124 & - & 1.725 & 0.229 & 0.771 & 1.902 \\
\hline 20 & Large demersal fishes & 3.497 & 0.038 & 1.08 & 4.20 & 0.855 & 0.257 & 0.227 & 0.697 & 0.156 & 0.210 & 0.223 & 0.321 & 0.679 & 0.038 \\
\hline 21 & Demersal fishes & 3.478 & 0.447 & 1.14 & 3.90 & 0.981 & 0.292 & 0.004 & 1.114 & 0.022 & 0.004 & 0.571 & 0.365 & 0.635 & 0.358 \\
\hline 22 & Benthic fishes & 3.484 & 0.280 & 1.3 & 5.175 & 0.736 & 0.251 & 0.025 & 0.932 & 0.343 & 0.019 & 0.310 & 0.314 & 0.686 & 0.386 \\
\hline 23 & Skates & 3.438 & 0.051 & 0.14 & 4.4 & 0.115 & 0.032 & 0.016 & - & 0.124 & 0.115 & 0.379 & 0.040 & 0.960 & 0.052 \\
\hline 24 & Predator crustaceans & 3.715 & 0.150 & 5 & 14.5 & 0.523 & 0.345 & - & 2.615 & 2.385 & - & 0.408 & 0.431 & 0.569 & 0.793 \\
\hline 25 & Predator molluscs & 3.334 & 0.288 & 4.5 & 20 & 0.873 & 0.225 & - & 3.927 & 0.573 & - & 0.263 & 0.281 & 0.719 & 1.317 \\
\hline 26 & Other predator invertebrates & 3.353 & 0.899 & 3.5 & 20 & 0.744 & 0.175 & 0.002 & 2.603 & 0.895 & 0.001 & 0.226 & 0.219 & 0.781 & 4.401 \\
\hline 27 & Omnivore invertebrates & 3.000 & 4.495 & 12 & 12 & 0.990 & 1.000 & 0.002 & 11.878 & 0.120 & - & 0.477 & 1.250 & -0.250 & 11.328 \\
\hline 28 & Crabs & 2.050 & 1.580 & 3.17 & 19 & 0.808 & 0.167 & - & 2.560 & 0.610 & - & 0.048 & 0.209 & 0.791 & 6.967 \\
\hline 29 & Shrimps & 2.050 & 2.673 & 6 & 20 & 0.348 & 0.300 & - & 2.088 & 3.912 & - & 0.048 & 0.375 & 0.625 & 21.149 \\
\hline 30 & Bivalves & 2.000 & 15.493 & 0.6 & 20.83 & 0.751 & 0.029 & - & 0.451 & 0.149 & - & - & 0.036 & 0.964 & 66.855 \\
\hline 31 & Polychaetes & 2.850 & 7.709 & 3.5 & 20.83 & 0.688 & 0.168 & - & 2.408 & 1.092 & - & 0.727 & 0.210 & 0.790 & 40.538 \\
\hline 32 & Other detritivore $\mathrm{i}$ & 2.000 & 4.215 & 4.5 & 12.2 & 0.429 & 0.369 & - & 1.930 & 2.570 & - & - & 0.461 & 0.539 & 21.117 \\
\hline 33 & Infauna & 2.000 & 4.215 & 14.6 & 40 & 0.598 & 0.365 & - & 8.730 & 5.870 & - & - & 0.456 & 0.544 & 58.463 \\
\hline 34 & Zooplankton & 2.000 & 3.6 & 104 & 248 & 0.092 & 0.419 & - & 9.530 & 94.470 & - & - & 0.524 & 0.476 & 518.652 \\
\hline 35 & Phytoplankton & 1.000 & 151 & 182.96 & - & - & - & - & - & 182.960 & - & - & - & - & 2744.4 \\
\hline
\end{tabular}

duction is indirectly important as a source of marine snow production. The biomass of benthic invertebrates is quite high and this resource is consumed by every functional group.

Demersal fishes, in general, provide the most prominent connection between the recycling of detritus and the top predator groups. In the present model, these top predators are the large demersal species, including some commercial fishes, and the demersal sharks, although the top predators are also eaten by some pelagic species. These demersal fishes are centrally important in transferring energy from the bottom to the water column, but pelagic species in the overlying system are important couplers as well. In the present model the trophic relationship between demersal and pelagic species was specified as exported and imported biomass, and this was a key pathway for constructing the trophic web. Although these species are important for the transfer of energy from the bottom to the water column, benthic invertebrates are also consumed by all trophic levels, showing a high level of omnivory (Table 3 ).

As benthic invertebrates occupy the lower levels of the food web, fish species are positioned higher in the web, and this is why the mean trophic level of catches is 3.5.
High scores for the OI are exhibited by tilefish (2.172), squid (1.725), cutlassfish (1.721), Argentine hake adult (1.470), bentho-pelagic fishes (1.102) and demersal sharks (1.049). Silver-rag driftfish, Brazilian cod, pink cusk-eel and Synagrops sp. also exhibited high OI values, but these were lower than 1 . The total connectance of the system is 0.224 and the system OI is 0.422 . This food web is comprised of organisms with highly diverse diet compositions.

The predation mortality of a group is the sum of the consumption of this group by the other groups, divided by their own biomass; the value ranges from 0 to 1 . In the present model the value of predation mortality is high on omnivore invertebrates (11.88), zooplankton (9.53), infauna (8.73), squid (6.53), predator molluscs (3.93), other predatory invertebrates (3.6), predatory crustaceans (2.62), crab (2.57), polychaetes (2.41), shrimp (2.09), hake juveniles (2.24), other detritivory invertebrates (1.93), demersal fish (1.12), Synagrops sp. (1.07), silver-rag driftfish (1.04) and benthic fishes (0.93).

High EE values were found for many groups: cutlassfish, Argentine hake, large bentho-pelagic fishes, silver-rag driftfish, pink cusk-eel, Synagrops sp., Bra- 


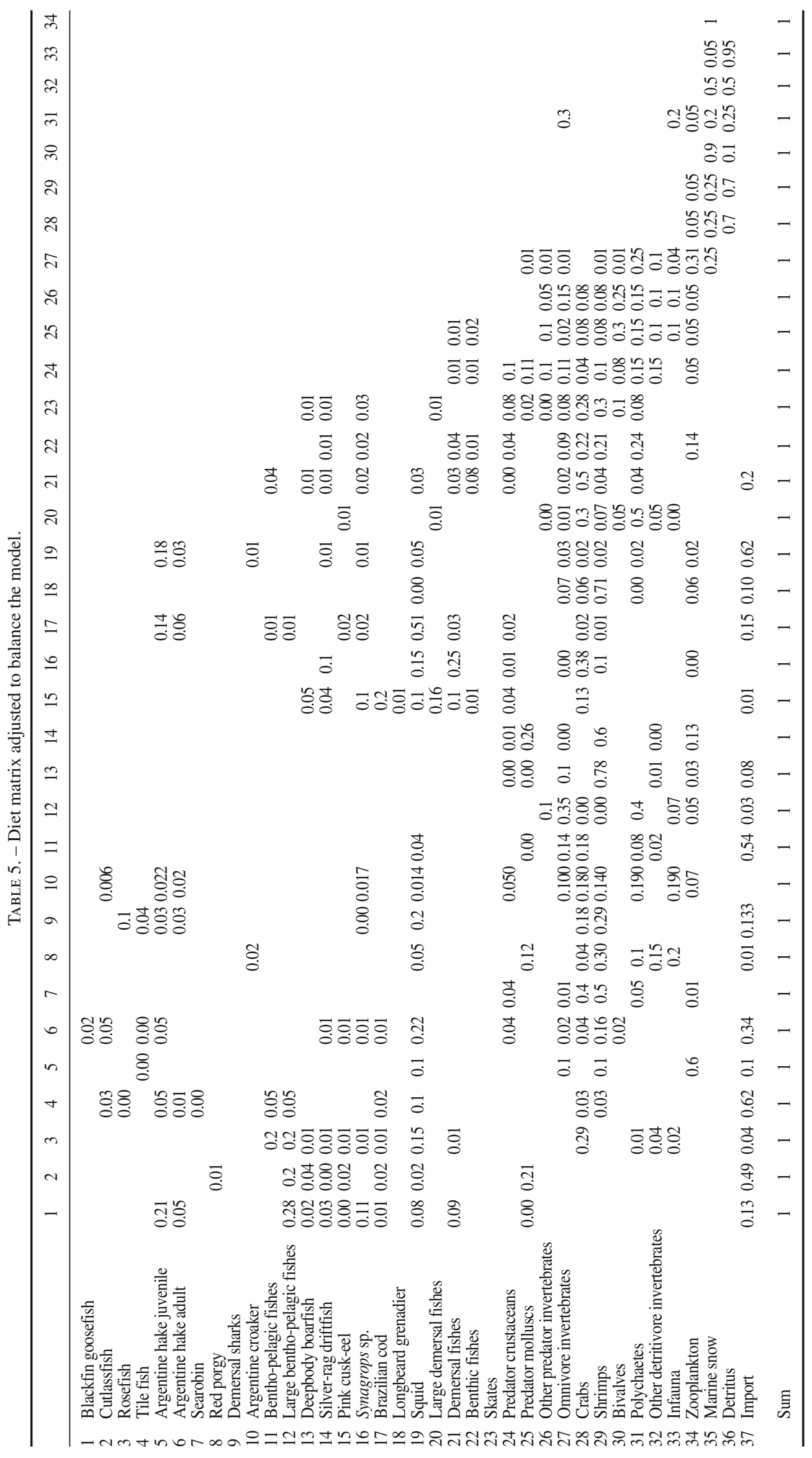

SCI. MAR., 76(4), December 2012, 763-779. ISSN 0214-8358 doi: 10.3989/scimar.03359.26A 


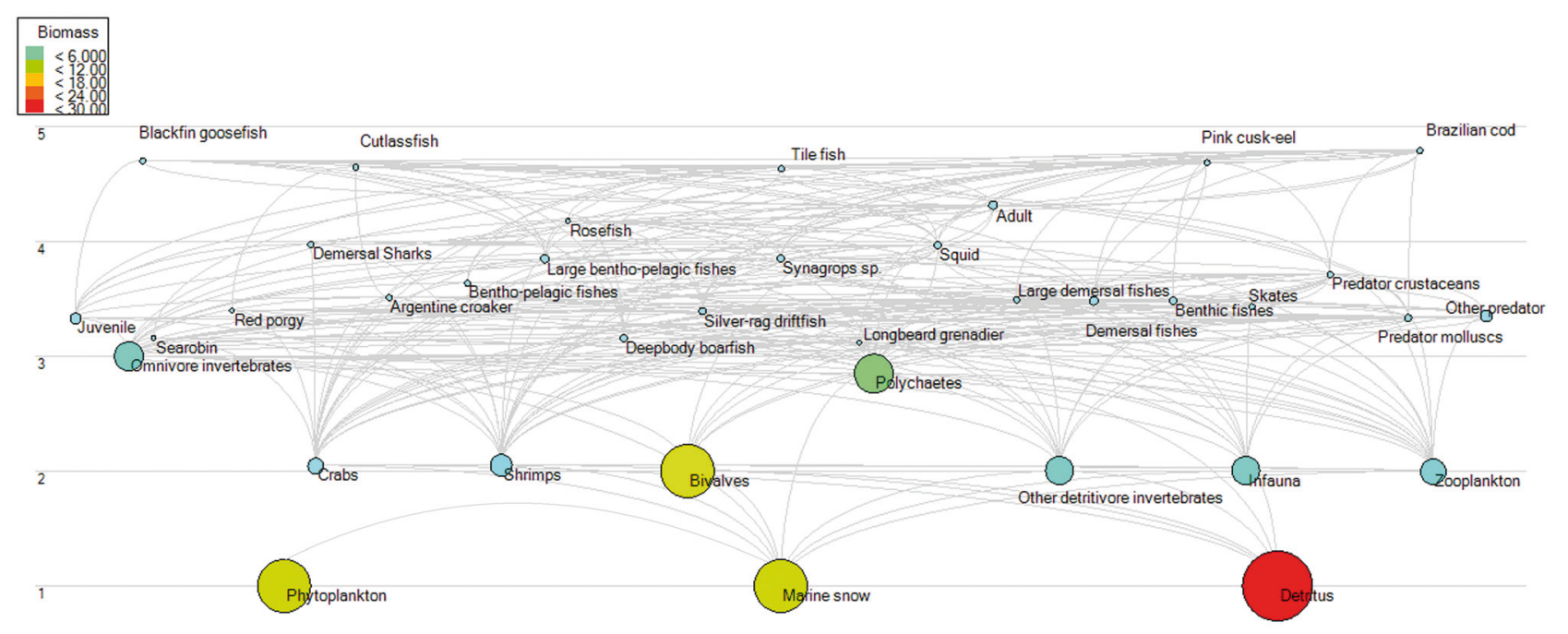

Fig. 2. - Trophic flow of demersal community of the outer continental shelf and upper slope of Southeastern Brazilian Bight the, size of the circles are proportional of its biomasses.

zilian cod, long beard grenadier, squid, large demersal fishes, demersal fishes and crab. This means that the biomasses produced by these species are highly utilized by other organisms in the system, calling for caution in management (conservative levels of exploitation) for these species in an ecosystem-based context.

The total biomass in the system, excluding detritus, is $64.332 \mathrm{t} \mathrm{km}^{-2}$. The relative ascendency $(\mathrm{A} / \mathrm{C})$ $(49.1 \%)$ indicates a high capacity of the system to withstand changes and to recover from disturbance. This high level of ascendency (and implied resilience) is probably related to the high level of omnivory of all compartments of this ecosystem.

Within EwE, network analysis uses two indices that are used to identify keystoneness of species or functional groups. In this model, both indices identified squid $(1 ; 0.205)$ as the highest scoring species in the system followed by polychaetes $(0.88 ; 0.1)$, Argentine hake adult $(0.836 ; 0.127)$, pink cusk-eel $(0.787 ; 0.103)$, omnivore invertebrates $(0.702 ; 0.0218)$, shrimp $(0.642$; $-0.0039)$, demersal sharks $(0.548 ;-0.0544)$, demersal fishes $(0.492 ;-0,104)$, Synagrops sp. $(0.461 ;-0.131)$, crab $(0.4 ;-0.213)$ and cutlassfish $(0,388 ;-0.205)$.

The mixed trophic impact analysis (Ulanowicz and Puccia 1990) shows that groups that are more negatively impacted by fisheries are skates, demersal sharks, red porgy and searobin. In addition, Argentine hake adult, pink cusk-eel, squid, predator molluscs and polychaetes have a strong negative effect on some other groups. Skates and sharks are probably strongly affected because they have a low biomass, slow growth and reproduction, and high level of discards. Red porgy and searobin support important fisheries, and according to Rossi-Wongtschowski et al. (2006) and Cergole et al. (2005), respectively, they are overexploited, although there are no direct assessments of the status of these stocks.

\section{DISCUSSION}

The southeastern Brazilian Bight outer continental shelf and upper slope biota is supported by detritus, which is consumed by benthic species, which in turn support benthivorous species. Squids, polychaetes, molluscs, demersal fishes and crustaceans in general are fundamental in this ecosystem, as they exhibit high interaction strengths in the food web, as indicated by the keystoneness indexes that are included in EwE. According to Paine (1966) and Mills et al. (1993), keystone species are important because they structure the ecosystem, and despite their low biomass, their loss would precipitate many further extinctions through their many connections with another species in the food web. The keystoneness indexes examined here emphasize the dominant interacting species for this ecosystem, but many of them are invertebrates that have high biomass. It is not surprising that these groups are dominant and fundamental to the structure and functioning of this detritus-based system, but they should not be considered keystone species (or keystone functional groups) because their biomasses, abundances, or both, are somewhat high rather than low relative to their interaction strength. It is thus more useful to simply call them "strong interactors" or "dominant species" rather than "keystone species" as the Libralato et al. (2006) index rates them. Based on this distinction, we can consider squids, Argentine hake adult, pink cusk-eel, demersal sharks, demersal fishes and Synagrops sp. to be keystones if it is indeed true that these groups have a relatively low biomass in this system, as estimated (Fig. 3)

Gasalla et al. (2007) also demonstrated the importance of the benthic community in the Southern Brazil Shelf Large Marine Ecosystem (continental shelf and slope), in which our study area is included, reinforcing the importance of detritus and organisms that 


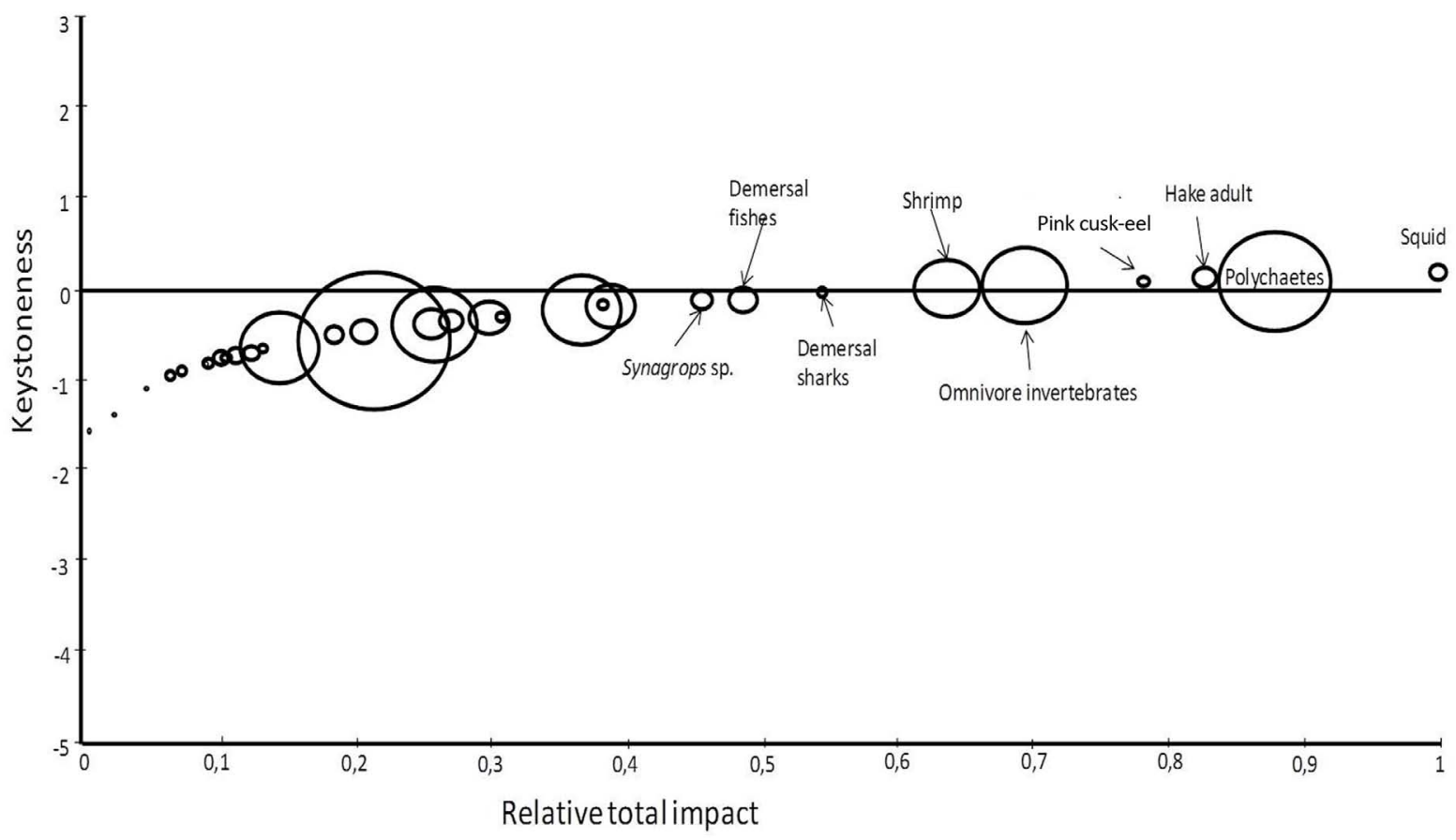

Fig. 3. - Graph of keystone species indices. Circles represent the functional groups; the sizes of each circle are proportional to the relative biomass of each functional group.

help recycle energy and matter in this system. These authors discuss the existence of a large amount of nektonic organisms that feed mainly benthic invertebrates. Velasco (2004) and Velasco and Castello (2005) also described the demersal community of the southern Brazil continental shelf ecosystem as highly important. In that case, however, he highlighted a pelagic species, the anchovy Engraulis anchoita, which was prominent in coupling demersal and pelagic sub-systems, eating benthic invertebrates and being prey of large fish predators, both demersal and pelagic.

Gasalla et al. (2007) and Freire et al. (2008) showed that the Brazilian shelf ecosystems have low primary production. Freire et al. (2008) say "The northeast sub-region, the object of this study, is characterized by rocky substrates and low primary production due to the influence of the warm North Brazil and Brazil currents." Gasalla et al. (2007; page 31) reported that the estimated phytoplankton biomass is $0.5 \mathrm{gC} / \mathrm{m}^{2} /$ day and that this value decreases as the depth increases. Gasalla et al. (2007) also state that mean primary production is high because of the existence of a front vortex that causes high productivity events. In the area modelled here, however, detritus was clearly of primary importance to the benthic community. Gasalla et al. (2007) first highlighted the low primary production in South Brazil Shelf large marine ecosystem. Freire et al. (2008) analysed the East Brazil Shelf large marine ecosystem and pointed out that primary production in this area is lower than in the South Brazil Shelf large marine ecosystem and that almost $95 \%$ of this production goes directly to detritus. Gasalla et al. (2007) reported that most of the primary production goes to the substrate and is recycled via the invertebrate benthic community. When our present results are added to these previous studies on Brazilian shelf and slope ecosystems, the principal importance of detritus in these settings seems unequivocal.

The mean trophic level of catches is high (3.5) and similar to the mean trophic level of catches found by Velasco (2004) (3.37), Gasalla et al. (2007) (3.56) and Freire et al. (2008) (3.4). These very high values are probably a characteristic of the Brazilian ecosystems and fisheries. The value of 3.5 corresponds to organisms of mid-trophic levels such as benthopelagic fishes and demersal fish in general. It occurs because catches in this ecosystem are still directed at top predators, almost in the same magnitude as crabs and shrimps, both of which are lower trophic level organisms.

The mixed trophic impact diagram shows prey competition for food, as was also observed by Antony et al. (2010). This competition can also be observed in the high mortality of invertebrates in general, all of which are important prey, and of Argentine hake juveniles in particular. Also, the keystone species index shows that squid, polychaetes and different kinds of demersal fishes are very important prey in this system. Therefore, by integrating the strong relationships of the lower trophic level organisms with the information about the high amount of detritus and the low primary production, we can infer that this community is shaped strongly from the bottom up.

This system has a high level of connections between its components, as is shown in the high values of connectance and omnivory. The organisms are 
strongly connected and have a high diversity of food (they are not specialists). Gasalla et al. (2007) also showed a high value for this index (0.23 and 0.337). Freire et al. (2008) found medium omnivory (0.21) for the East Brazil Shelf large marine ecosystem, and Rocha et al. (2007) also found intermediate values for the channel of São Sebastião (0.26 and 0.21) and São Sebastião inner shelf $(0.21$ and 0.25$)$, both in part of the area of the present study. Although the values of Rocha et al. (2007) and Freire at al. (2008) are not as high as those of the present paper and those of Gasalla et al. (2007), they are still high. Perhaps the high connectance among organisms in a system and high levels of omnivory are characteristic of tropical and subtropical waters, as can be observed in land ecosystems such as forests (Greenberg 1981, Boedmer 1989) where the biodiversity is high. The high level of ascendency indicated for this system indicates a high capacity of the system to withstand changes and to recover from disturbance (Odum 1969, Christensen 1995) and is probably related to the high level of omnivory of all compartments of this ecosystem

High EE values indicated for some species reflects the consumption of large proportions of the production of these groups within the system (Christensen et al. 2008). It can occur sometimes because the species are highly exploited in the system or because they experience a high level of predation. In this study the cutlassfish, with the highest EE, is heavily fished (also often discarded) and pursued by the sport fishery. Moreover, this species has undergone an increase in its catch in the last 15 years that is not well reported (Cergole et al. 2005). Argentine hake, pink cusk-eel, Brazilian cod, squid and crab are highly consumed and fished in the system, being some of the most important resources in the demersal trawls (Cergole et al. 2005, RossiWongtschowski et al. 2006, Valentini and Pezzuto 2006). Demersal fishes, large demersal fishes, large bentho-pelagic fishes, silver-rag driftfish, Synagrops sp. and longbeard grenadier are heavily consumed and are also important components in this system. These high EE values can indicate that these species are at risk and reinforce the calls by Cergole et al. (2005), Rossi-Wongtschowki et al. (2006) and Valentini and Pezzuto (2006) for a suitable management plan for the fishery in this area.

The main difficulty in balancing this model was related to the low biomass of a few functional groups that were subject to high levels of consumption and exploitation. Several factors were involved. First, the biomass estimates were calculated from trawl surveys and this kind of sampling is suitable only for some groups and sizes, but not for all organisms in an ecosystem. Second, the trawl gear did not completely touch the bottom, so benthic fishes and invertebrates were able to escape during sampling. Benthic invertebrates can also escape from benthic samplers such as dredges and sleds. Third, various studies indicate that several of these species were overexploited prior to 2001, the year in which the data were collected (Valentini and Pezuto 2006), thus indicating less biomass than is naturally supported by the system. This situation is very clear for benthic fishes, of which the most important are species of the genus Paralichthys, which support an important fishery and are also discarded. This group is clearly overexploited according to Cergole et al. (2005). The benthic fish functional group was the most difficult to balance; it was necessary to considerably increase its biomass estimate, probably indicating that the population was not supporting the catches, i.e. implying biomass depletion in the model year.

Fisheries policy measures in Brazil are not very appropriate, and sometimes non-existent, allowing a "gold-rush" pattern for some resources after economic discovery (Velasco and Castello 2005), as happened recently with the blackfin goosefish, which went from a discard to an overexploited species in less than 10 years (Valentini and Pezzuto 2006). Despite the current policy shortcomings, this system is recovering from some disturbances because it has a high level of ascendency and overhead. These measures indicate the reserve and the capacity of the system to recover after a disturbance (Ulanowicz 1986) - resistance and resilience. Despite the diversity, high indicated connectance, and high recovery capacity, this system is being highly impacted by fisheries due to their scale and efficiency, and because of the lack of strong catch controls. The lack of knowledge of the impacts on a system that is out of sight is allowing a loss of structure, function, and biodiversity. We strongly recommended that the policy and management of the fishery be improved, as suggested by Cergole et al. (2005), Rossi-Wongtschowski et al. (2006) and Valentini and Pezzuto (2006), and that increased investments be made in basic research.

\section{CONCLUSIONS}

Our modelling exercise indicated that the outer continental shelf and upper slope biological communities of the southeastern Brazilian Bight are shaped from bottom-up and are supported prominently by detritus, with a high diversity of detritus-supported species and high omnivory throughout the biological community. The demersal fishes are a key, highly connected link between the detritus-supported lower trophic levels and the biological communities of the upper water column, indicating that considerable caution is needed regarding the exploitation of demersal fish stocks from a broader ecosystem and social-ecological perspective. High levels of ascendency indicated by the constructed model, probably related to the high level of omnivory, may indicate that this system has a relatively high capacity to recover from disturbances, but it assumes that disturbances are non-catastrophic and subside. In contrast, unmanaged and uncontrolled fishing for demersal species has increased in this area over the last 20 years, and the scale of depletion and degradation will likely overwhelm the theoretical resistance or re- 
silience of this biological community and quickly lead to a considerably degraded ecosystem and diminished services. Immediate improvements are needed in the policy and management of the uncontrolled fisheries in this region, including explicit investments in the capacities for monitoring the status and integrity of stocks and whole biological communities, identifying and monitoring the social-ecological services they provide, fishing community commitment and enforcement, and management strategy development, evaluation, and adaptation. We strongly recommend the development of an appropriate management plan for the fisheries, in agreement with other researchers working in this area.

\section{ACKNOWLEDGEMENTS}

We wish to thank to CAPES and CNPq for the scholarship. The REVIZEE-Score Sul programme, and particularly Dr. Carmen L.D.B. Rossi-Wongtschowski, provided scientific support and data. The Programa de Pós Graduação em Ecologia - UNICAMP and UBC Fisheries Centre provided support and facilities. Special thanks are due to Dr. Marta Coll for very valuable suggestions that improved the manuscript. We also thank the Pew Fellows Programme in Marine Conservation through the Pew Environment Group for supporting the participation and contribution of TAO.

\section{REFERENCES}

Allen R. 1971. Relation between production and biomass. J. Fish. Res. Board. Can. 28: 1573-1581.

Amaral A.C.Z., Rossi-Wongtschowski C.L.D.B. 2004. Biodiversidade bentônica da região Sudeste-Sul do Brasil - plataforma externa e talude superior. Série documentos REVIZEE, Instituto Oceanográfico da Univ. de São Paulo, São Paulo. 216 pp.

Andrade H.A., Lucato S.H.B., Almeida L.R., Cerchiari E. 2005. Prionotus punctatus (Bloch, 1793). In: Cergole M.C., Ávilada-Silva A.O., Rossi-Wongtschowski C.L.D.B. (eds.), Análise das Principais Pescarias Comerciais da Região Sudesde-Sul do Brasil: Dinâmica Populacional das Espécies em Explotação. Série documentos REVIZEE, Instituto Oceanográfico da Univ. de São Paulo, pp. 139-144.

Angelescu V., Prenski L.B. 1987. Ecologia trófica de la merluza común (Merluccidae, Merluccius hubbsi). Parte 2. Dinámica de la alimentación analizada sobre la base de las condiciones ambientales, la estructura y las evaluaciones de los efectivos en su área de distribución. Contr. INIDEP, Mar del Plata. 561: 1-205.

Antony P.J., Dhanya S., Lyla P.S., Kurup B.M., Ajmal Khan S. 2010. Ecological role of stomatopods (mantis shrimps) and potential impacts of trawling in a marine ecosystem of the southeast coast of India. Ecol. Model. 221: 2604-2614.

Bakun A. 1996. Patterns in the Ocean: Preocess: Ocean Process and Marine Population Dynamics. California Sea Grand College System. 324 pp.

Bautista-Vega A.A., Letourner Y., Harmelin-Vivien M., SalenPicard C. 2008. Difference in diet and size-related trophic level in two sympatric fish species, the red mullets Mullus barbatus and Mullus surmuletus, in the Gulf of Lions (north-west Mediterranean Sea). J. Fish Biol. 73(10): 2402-2420.

Bezzi S., Cañete G., Pérez M., Renzi M., Lassen H. 1994. Report of the INIDEP Working group on assessment of Hake (Merluccius hubbsi) North of $48^{\circ} \mathrm{S}$ (Southwest Atlantic Ocean). INIDEP Doc. Cient. 3: 5-28.

Boedmer R.E. 1989. Ungulate biomass in relation to feeding strategy within Amazonian forests. Oecologia 81: 457-550.

Bonham K., Sanford F.B., Clegg W., Bucher G.C. 1949. Biological and vitamin A studies of dogfish (Squalus suckleyi) landed in the State of Washington. Wash. Dept. Fish. Biol. Bull. 49(A): 83-113.

Brey T. 1991. Population dynamics of Sterechinus antarticus (Echinodermata: Echinoidea) on the Weddell Sea Shelf and Slope, Antartica. Antarct. Sci. 3(3): 251-256.

Brown D.R., Leonarduzzi E., Machinandiarena L. 2004. Age, growth and mortality of hake larvae (Merluccius hubbsi) in the north Patagonian shelf. Sci. Mar. 68(2): 273-283.

Carneiro M.H. 1995. Reprodução e alimentacão dos linguados Paralichthys patagonicus e Paralichthys orbignyanus (Pleuronectiformes: Bothidae) no Rio Grande do Sul, Brasil. M.Sc. thesis, Fund. Univ. do Rio Grande. 80 pp.

Carvalho M.R., Soares L.S.H. 2006. Diel feeding pattern and diet of rough scad Trachurus lathami Nichols, 1920 (Carangidae) from the Southwerstern Atlantic. Neotrop. Ichthyol. 4(4): 419-426.

Casarini L.M. 2006. Dinâmica populacional de raias demersais dos gêneros Atlantoraja e Rioraja (Elasmobranchi, Rajidae) da costa sudeste e sul do Brasil. PhD thesis, Univ. de São Paulo. 206 pp.

Cergole M.C., Ávila-da-Silva A.O., Rossi-Wongtschowski C.L.D.B. 2005. Análise das Principais Pescarias Comerciais da Região Sudesde-Sul do Brasil: Dinâmica Populacional das Espécies em Explotação. Série documentos REVIZEE, Instituto Oceanográfico da Univ. de São Paulo, São Paulo. 176 pp.

Christensen V. 1995. Ecosystem maturity - towards quantification. Ecol. Model. 77: 3-32.

Christensen V., Pauly D. 1992. ECOPATH II — a software for balancing steady-state ecosystem models and calculating network characteristics. Ecol. Model. 61: 169-185.

Christensen V., Walters C.J. 2004.Ecopath with Ecosim: methods, capabilities and limitations. Ecol. Model. 172: 109-139.

Christensen V., Walters C.J., Pauly D., Forrest R. 2008. Ecopath with Ecosim version 6 User Guide. Lenfest Ocean Futures Project. 235 pp.

Cohen D.M., Inada T., Iwamoto T., Scialabba N. 1990. FAO species catalogue. Vol. 10. Gadiform fishes of the world (Order Gadiformes). An annotated and illustrated catalogue of cods, hakes, grenadiers and other gadiform fishes known to date. FAO Fish. Synop. 125(10): 442 pp.

Coll M., Santojanni A., Palomera I., Tudela S., Arneri E. 2007. An ecological model of Northern and Central Adriatic Sea: Analysis of ecosystem structure and fishing impacts. J. Mar. Syst. 67: $119-154$.

Eleutério C.L.T. 2008. Crescimento, idade e mortalidade do congrorosa Genypterus brasiliensis (Regan 1903) na região Sudeste e Sul do Brasil. MSc thesis. Inst. Pesca de São Paulo. 60 pp.

Casarini L.M. 2006. Dinâmica populacional de raias demersais dos gêneros Atlantoraja e Rioraja (Elasmobranchi, Rajidae) da costa sudeste e sul do Brasil. PhD thesis, Univ. de São Paulo. $206 \mathrm{pp}$.

Freire K.M.F., Christensen V., Pauly D. 2008. Description of the East Brazil Large Marine Ecosystem using a trophic model. Sci. Mar. 72(3): 477-491.

Froese R., Pauly D. (eds.). 2010. FishBase. World Wide Web electronic publication. www.fishbase.org, version (09/2010)

Gasalla M.A., Rodrigues A.R., Postuma F.A. 2010. The trophic role of the squid Loligo plei as a keystone species in the South Brazil Bight ecosystem. ICES J. Mar. Sci. 67: 1413-1424.

Gasalla M.A., Velasco G., Rossi-Wongtschowski C.L.D.B., Haimovici M., Madureira, L.S.P. 2007. Modelo de equilíbrio de biomassa do ecossistema marinho da Região Sudeste-Sul do Brasil entre 100-1000 $\mathrm{m}$ de profundidade. Série documentos REVIZEE, Instituto Oceanográfico da Univ. de São Paulo, São Paulo. 56 pp.

Greenberg R. 1981. The Abundance and Seasonality of Forest Canopy Birds on Barro Colorado Island, Panama. Biotropica 13(4): 241-251.

Haimovici M. 2007. A prospecção pesqueira e abundância de estoques marinhos no Brasil das décadas de 1960 a 1990: levantamento de dados e avaliação crítica. MMA/SMCQA, Brasília. $330 \mathrm{pp}$.

Haimovici M., Arruda M.C., Teixeira R.L. 1989. Alimentação da Castanha Umbrina canosai no litoral sul do Brasil. Rev. Bras. Biol. 49(2): 511-522.

Haimovici M., Cousin J.C.B. 1989. Reproductive biology of the castanha Umbrina canosai in southern Brazil. Rev. Bras. Biol. 49(2): 523-537.

Haimovici M., Miranda L.W., Absalonsen L., Velasco G. 2006. Diagnóstico e orientações para o ordenamento pesqueiro de Umbrina 
canosai. In: Cergole M.C., Ávila-da-Silva A.O., Rossi-Wongtschowski C.L.D.B. (eds.), Análise das principais pescarias comerciais da região sudeste-sul do Brasil: dinâmica populacional das espécies em explotação. Série documentos REVIZEE, Instituto Oceanográfico da Univ. de São Paulo, pp. 77-85.

Haimovici M., Reis E.G. 1984. Crescimento: determinação de idade de crescimento da castanha Umbrina canosai, (Pisces, Scianidae) do sul do Brasil. Atlantica 7: 25-45

Haimovici M., Rossi-Wongtschowski C.L.D.B., Ávila-Bernardes R., Fischer L.G., Vooren C.V., Santos R.A., Rodrigues A.R., Santos S. 2008. Prospecção pesqueira de espécies demersais com rede de arrasto-de-fundo na Região Sudeste-Sul do Brasil. Série documentos REVIZEE, Instituto Oceanográfico da Univ. de São Paulo, São Paulo. 183 pp.

Haimovici M., Velasco G. 2000. Relações comprimento peso de peixes teleósteos marinhos do sul do Brasil com uma avaliação de diferentes métodos de ajuste. Atlantica. 22: 131-140.

IBAMA 2008. Estatística da pesca 2006 Brasil: grandes regiões e unidades da federação. Instituto Brasileiro do Meio Ambiente e dos Recursos Naturais Renováveis. Imprensa Oficial, Brasília. 174 pp.

Ikeda T., Shiga N. 1999. Production, metabolism and production/ biomass (P/B) ratio of Themisto japonica (Crustacea: Amphipoda) in Toyama Bay, Southern Japan Sea. J Plankton Res. 21(2): 299-308.

Jørgensen S.E. 1979. Handbook of Environmental Data and Ecological Parameters. International Society of Ecological Modelling. $1162 \mathrm{pp}$.

Kotlyar A.N. 1987. Age and growth of alfoncino, Berix splendens. J. Ichthyol. 27: 104-111.

Libralato S., Christensen V., Pauly D. 2006. A method for identifying keystone species in food web models. Ecol. Model. 195(34): 153-171.

Madureira L.S.P., Rossi-Wongtschowski C.L.D.B. 2005. Prospecção de recursos pesqueiros pelágicos na Zona Econômica Exclusiva da Região Sudeste-Sul do Brasil: hidroacústica e biomassas. Série documentos REVIZEE, Instituto Oceanográfico da Univ. de São Paulo, São Paulo. 144 pp.

Magro M. 2005 Trichiurus lepturus Linnaeus, 1758. In: Cergole M.C., Ávila-da-Silva A.O., Rossi-Wongtschowski C.L.D.B. (eds.), Análise das principais pescarias comerciais da região sudeste-sul do Brasil: dinâmica populacional das espécies em explotação. Série documentos REVIZEE, Instituto Oceanográfico da Univ. de São Paulo, pp. 162-163.

Martins A.S, Haimovici M., Palacios R. 2005. Diet and feeding of the cutlassfish Thrichiurus lepturus in the Subtropical Convergence Ecosystem of Southern Brazil. J. Mar. Biol. Ass. U.K. 85(5): 1223-1229.

Martins R.F. 2002. Loliginídeos na Ilha de Santa Catarina: Características e relações ecológicas, com ênfase em Loligo plei (Cephalopoda: Euthida: Myopsina). M.Sc. thesis, Univ. do Paraná. 199 pp.

Martins R.S., Haimovici M. 2000. Determinação de idade, crescimento e longevidade da abrótea de profundidade, Urophycis cirrata, Goode and Bean, 1896, (Teleostei; Phycidae) no extremo sul do Brasil. Atlantica 22: 57-70.

Martins R.S., Perez J.A.A., Schettini C.A.F. 2006. The squid around Santa Catarina Island, Southern Brazil: Ecology and Interactions With the Coastal Oceanographic Environment. J. Coast. Res. Spec. Issue. 39: 1285-1290.

Ménard F., Gentil F., Dauvin J.C. 1989. Population dynamics and secondary production of Owenia fusiformis Delle chiaje from the Bay of Seine (Eastern English Channel). J. Exp. Mar. Biol. Ecol. 133: 151-167.

Metri C.B. 2007. Biologia pesqueira de Artemesia longinaris (Bate, 1888) (Decapoda, Dendrobranchiata, Penaeidae) e de Pleoticus muelleri (Bate, 1888) (Decapoda, Dendrobranchiata, Solenoceridae) no Sul do Brasil. $\mathrm{PhD}$ thesis, Univ. do Paraná. $221 \mathrm{pp}$.

Mills L.S., Soulé M.E., Doak D.F. 1993. The keystone-species concept in ecology and conservation. BioScience 43(4): 219-224.

MMA - Ministério do Meio Ambiente. 2006. Programa REVIZEE: avaliação do potencial sustentável de recursos vivos na zona econômica exclusiva: relatório executivo/MMA, Secretaria de Qualidade Ambiental. 279 pp.

Morato T., Solà E., Grós M.P., Menezes G.M. 1999. Diets of forkbeard (Phycis phycis) and conger eel (Conger conger) off the Azores during spring of 1996 and 1997. Arq. Life Mar. Sci. 17(A): 51-64.
Muto Y.E., Silva M.H.C., Vera. G.R., Leite S.S.M., Navarro D.G. Rossi-Wongtschowski C.L.D.B. 2005. Alimentação e relações tróficas de peixes demersais da plataforma continental externa e talude superior da região sudeste e sul do Brasil. Série documentos REVIZEE, Instituto Oceanográfico da Univ. de São Paulo, São Paulo. 64 pp.

Nascimento M.C. 2006. Alimentação de peixes na plataforma continental externa e talude superior na região Sudeste-Sul do Brasil. MSc thesis, Univ. Paulista. 89 pp.

Nobre-leal L.C., Bemvenuti M.A. 2006. Levantamento e caracterização dos peixes mais frequentes no mercado público do Rio Grande. Cad. Ecol. Aquat. 1(1): 45-61.

Odum H. T. 1969. The strategy of the ecosystem development. Science 164: 262-270.

Okey T.A. 2004. Shifted community states in four marine ecosystems: some potential mechanisms. PhD thesis, Univ. British Columbia. 173 pp.

Omenta E.P., Amaral A.C.Z. 2000. Population dynamics and secondary production of Laeonereis acuta (Treadwell, 1923) (Nereididae: Polychaeta). Bull. Mar. Sci. 67(1): 421-431.

Paine R.T. 1966. Food web complexity and species diversity. Am. Nat. 100: 65-75.

Palomares M.L.D., Pauly D. 1998. Predicting food consumption of fish populations as functions of mortality, food type, morphometrics temperature and salinity. Mar. Freshwater Res. 49: 447-453.

Pauly D. 1980. On the interrelationships between natural mortality, growth parameters, and mean environmental temperature in 175 fish stocks. J. Cons. int. Explor. Mer.39(2): 175-192.

Pauly D., Christensen V. 1993. Trophic models of aquatic ecosystems. ICLARM Conf. Proc. 26: 390

Pauly D., Christensen V., Walters C. 2000. Ecopath, Ecosim, and Ecospace as tools for evaluating ecosystem impact of fisheries. ICES J. Mar. Sci. 57: 697-706.

Perez J.A.A., Pezzuto P.R., Andrade H.A. 2005. Biomass assessment of the monkfish Lophius gastrophysus stock exploited by a new deep-water fishery in southern Brazil. Fish. Res. 72: $149-162$.

Perez J.A.A., Pezzuto P.R., Andrade H.A., Schwingel P.R., Rodrigues-Ribeiro M., Wharlich R. 2002. O ordenamento de uma nova pescaria direcionada ao peixe-sapo (Lophius gastrophysus) no Sudeste e Sul do Brasil. Notas Téc. FACIMAR. 6: 65-83.

Perez J.A.A., Pezzuto P.R., Rodrigues L.F., Valentini H., Vooren, C.M. 2001. Relatório da reunião técnica de ordenamento da pesca de arrasto nas regiões Sudeste e Sul do Brasil. 07- a 11 de maio de 2001. CEPSUL/IBAMA, Itajaí, SC. Notas Téc. FACIMAR. 5: 1-34.

Perez J.A.A., Wahrlich R., Pezzuto P.R., Lopes, F.R.A. 2002b. Estrutura e dinâmica da pescaria do peixe-sapo Lophius gastrophysus no sudeste e sul do Brasil. Bol Tec. Inst. Pesca São Paulo. 28(2): 205-231.

Pires-Vanin A.M.S. 2008. Oceanografia de um Ecossistema Subtropical: Plataforma de São Sebastião, SP. Ed. Univ. de São Paulo, São Paulo. 462 pp.

Polovina J.J. 1984. An overview of the ECOPATH model. Fishbyte. 2(2): $5-7$.

Power M.E., Tilman D., Estes J.A., Menge B.A., Bond W.J., Mills L.S., Daily G., Castilla J.C., Lubchenco J., Paine R.T. 1996. Challenges in the quest for keystones. Bioscience 46: 609-620.

Ribeiro M.A.G. 1982. Crustacea (em especial amphipoda) do conteúdo estomacal de sciaenidae da plataforma continental do Brasil (Lat $29^{\circ} 21^{\prime}$ 'S e $30^{\circ} 41$ 'S). M.Sc. thesis, Univ. de São Paulo. 97 pp.

Rocha G.R.A., Rossi-Wongtschowski C.L.D.B., Pires-Vanin A.M.S., Soares L.S.H. 2007. Thophic models of São Sebastião Channel and continental systems, SE Brazil. Pan-Am. J. Аqua. Sci. 2: 149-162.

Rodrigues A.R. 2007. Caracterização da estrutura populacional e alimentação das lulas Loligo plei (Blainville, 1823) e Loligo sanpaulensis (Brakoniecki, 1984) (Cephalopoda: Loliginidae) capturada pela pesca industrial do Estado de São Paulo, entre $23^{\circ} \mathrm{S}$ e $26^{\circ} 55^{\prime} \mathrm{S}$. M.Sc. thesis, Inst. Pesc. de Santos. 87 pp.

Rossi-Wongtschowski C.L.D.B., Ávila-da-Silva A.O., Cergole M.C. 2006. Análise das principais pescarias comerciais do Sudeste-Sul do Brasil: dinâmica populacional das espécies em explotação-Vol. II. Série documentos REVIZEE, Instituto Oceanográfico da Univ. de São Paulo, São Paulo. 96 pp. 
Rossi-Wongtschowski C.L.D.B., Madureira L.S-P. 2006. O Ambiente Oceanográfico da Plataforma Continental e do Talude na Região Sudeste-Sul do Brasil. Ed. Univ. de São Paulo, São Paulo. $472 \mathrm{pp}$.

Ruppert E.E., Fox R.S., Barnes R.D. 2005. Zoologia dos invertebrados. $7^{\circ} \mathrm{ed}$, ROCA, São Paulo 1145 pp.

Saccardo J.H. 1983. Biología y disponibilidad de sardina (Sardinella brasiliensis Steindachneer, 1879) em La costa sudeste del Brasil. In: Sharp G.D., Csirke J. (eds.). Proceedings of the Expert Consultation to Examine Changes in Abundance and Species Composition of Neritic Fish resources. FAO Fish Rep. 291. pp. 449-464.

Sánches F. 2009. Alimentación de la Merluza (Merluccius hubbsi) en El Golfo San Jorge y águas adyacentes. INIDEP Inf. Téc 75: $24 \mathrm{pp}$.

Sanches W.O.C. 1994. Feeding ecology of castañeta (Cheilodactylus bergi: Pisces, Cheilodactylidae) in the Southwestern Atlantic $\left(34^{\circ}-47^{\circ}\right.$ S). Aust. J. Mar Fresw. Res. 45: 507-520.

Santos P.J.P. 1994. Population dynamics and production of Scolelepis gaucha (Polychaeta: Spionidae) on the sandy beaches of Southern Brazil. Mar. Ecol. Progr. Ser. 110: 159-165.

Santos R.A., Haimovici M. 1997. Food and feeding of the shortfinned squid Illex argentinus (Cephalopoda: Ommastrephidae) off southern Brazil. Fish. Res. 33: 139-147.

Santos R.A., Haimovici M. 2000. The Argentine short-finned squid Illex argentinus in the food webs of southern Brazil. Sarsia 85 49-60.

Schwingel P.R., Andrade H.A. 2002. Capítulo 3: Aspectos biológicos e populacionais. In: Perez J.A.A., Andrade H.A., Pezzuto P.R., Rodrigues-Ribeiro M., Schwingel P.R., Wahrlich R. Análise da Pescaria do Peixe-sapo no Sudeste e Sul do Brasil. Convenio UNIVALI MAPA, Itajaí, pp. 1-27.

Schwingel P.R., Assunção R. 2009. Hábitos alimentares da raia Atlantoraja platana (Günter, 1880) (Elasmobranchii, Rajidae) no litoral norte de Santa Catarina, Brasil. Pan-Am. J. Aqua. Sci. 4(4): 446-455.

Soares L.S.H. 1992. Alimentação de espécies de peixes demersais ao longo do ciclo diário no litoral de Ubatuba. São Paulo: alimento, atividade alimentar e consumo. $\mathrm{PhD}$ thesis, Univ. de São Paulo. 165 pp.

Souza J.R.B.S., Borzone C.A. 2000. Population dynamics and secondary production of Scolelepsis squamata (Polychaeta: Spionidae) in an exposed sandy beach of Southern Brazil. Bull. Mar Sci. 67(1): 221-233.

Tubino, R.A. 1999. Distribuição e ecologia alimentar de três espécies de peixes demersais da família Triglidae: Prionotus punctatus, Prionotus nudigula $e$ Bellator brachychir na região de ressurgência de Cabo Frio, Brasil. MSc thesis, Univ. Fluminense. 83 pp.
Ulanowicz R.E. 1986. Growth and development: ecosystem phenomenology. Springer Verlag, New York. 203 pp.

Ulanowicz R.E., Puccia C.J. 1990. Mixed trophic impacts in ecosystems. Coenoses. 5: 7-16.

Valentini H., Pezzuto P.R. 2006. Análise das principais pescarias comerciais da Região Sudeste-Sul do Brasil com base na produção controlada do período 1986-2004. Série documentos REVIZEE, Instituto Oceanográfico da Univ. de São Paulo, São Paulo. 46 pp.

Vaz-dos-Santos A.M. 2006. Identificação de estoques da merluza, Merluccius hubbsi Marini, 1933 (Gadiformes: Merlucciidae) na Região Sudeste-Sul do Brasil. PhD thesis, Univ. de São Paulo. 196 pp.

Vaz-dos-Santos A.M., Rossi-Wongtschowski C.L.D.B. 2005. Merluccius hubbsi Marini, 1933. In: Cergole M.C., Ávila-daSilva A.O., Rossi-Wongtschowski C.L.D.B. (eds.), Análise das Principais Pescarias Comerciais da Região Sudesde-Sul do Brasil: Dinâmica Populacional das Espécies em Exploração. Série documentos REVIZEE, Instituto Oceanográfico da Univ. de São Paulo, São Paulo. pp. 88-93.

Vaz-dos-Santos A.M., Rossi-Wongtschowski C.L.D.B. 2007. Age and growth of the Argentine hake Merluccius hubbsi (Marini, 1933 ) in the Brazilian South-Southeast Region during 19962001. Neotrop. Ichthyol. 5(3): 375-386.

Vaz-dos-Santos A.M., Rossi-Wongtschowski C.L.D.B., Figueiredo J.L. 2009. Parâmetros da reprodução e relação comprimentopeso da merluza Merluccius hubbsi (Teleostei: Merlucciidae), estoque sudeste brasileiro $\left(21^{\circ} \mathrm{S}-29^{\circ} \mathrm{S}\right)$, ano 2004 . Bol. Tec. Inst. Pesca. São Paulo. 35(1): 1-16.

Velasco G. 2004. Modelo eco-trófico do ecossistema da plataforma continental do sul do Brasil e cenários de exploração pesqueira da anchoíta (Engraulis anchoita) e do peixe-lanterna (Maurolicus stehmanni). PhD thesis, Fund. Univ. do Rio Grande. 154 p.

Velasco G, Araújo J.N., Castello J.P., Oddone M.C. 2007. Exploring MSY strategies for elasmobranch fishes in an ecosystem perspective. Pan-Am. J. Aqua. Sci. 2(2): 163-178.

Velasco G., Castello J.P. 2005. Preliminary ecotrophic model of southern Brazil continental shelf and fisheries scenarios for Engraulis anchoita (Pisces, Engraulidae). Atlantica 7(1): 59-68.

Vetter E.W. 1996. Secondary production of a Southern California Nebalia (Crustacea: Leptostraca). Mar. Ecol. Progr. Ser. 137: 95-101.

Walters C.J., Christensen V., Pauly D. 1997. Structuring dynamic models of exploited ecosystems from trophic mass-balanced assessments. Rev. Fish. Biol. Fish. 7: 139-172.

Scient. ed.: J.G. Hiddink.

Received February 8, 2011. Accepted April 3, 2012.

Published online October 26, 2012. 


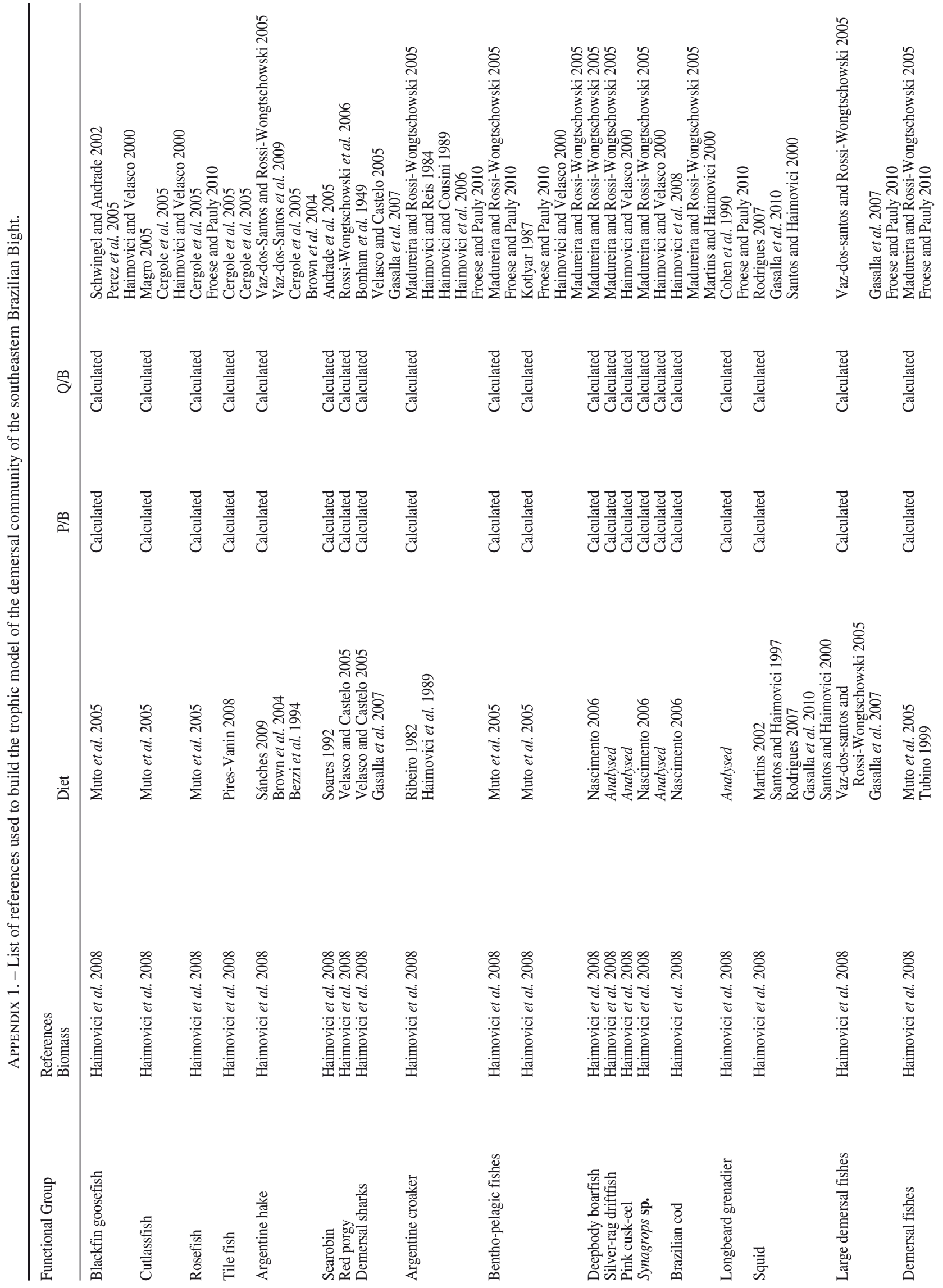


TROPHIC MODEL OF SOUTHEASTERN BRAZIL DEMERSAL COMMUNITY • 779

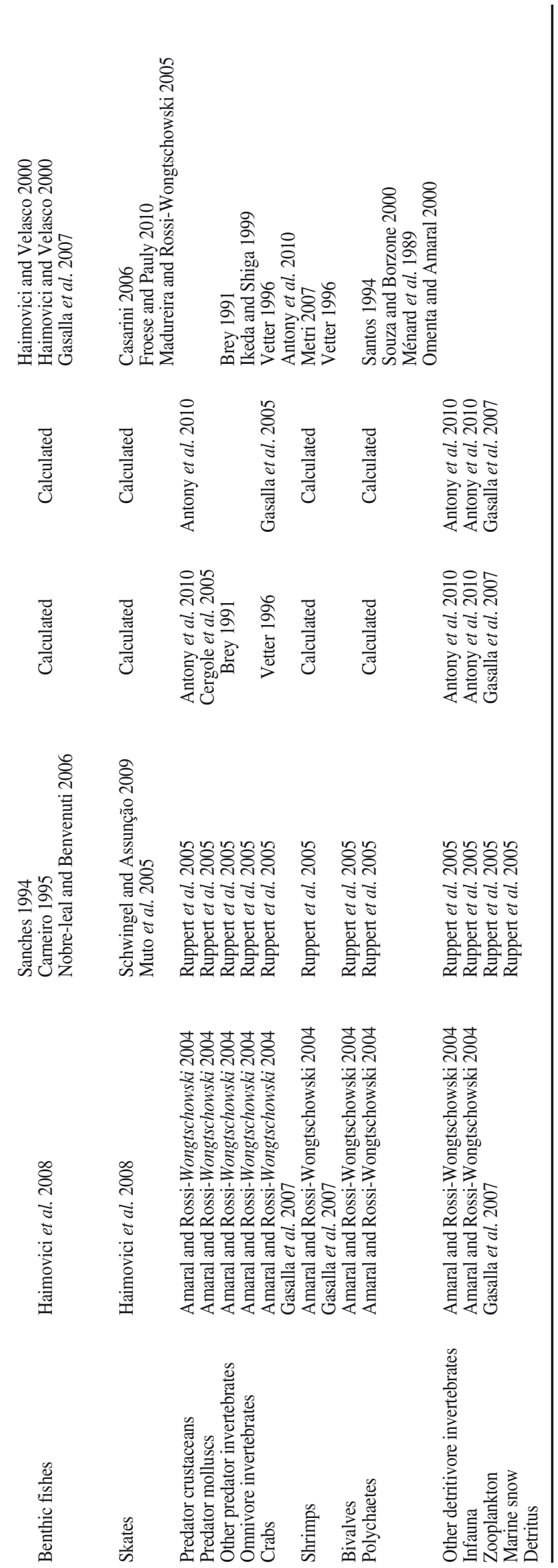

SCI. MAR., 76(4), December 2012, 763-779. ISSN 0214-8358 doi: 10.3989/scimar.03359.26A 